\title{
Soil organic carbon stock in Abune Yosef afroalpine and sub-afroalpine vegetation, northern Ethiopia
}

\author{
Kflay Gebrehiwot ${ }^{12^{*}} \mathbb{D}$, Temesgen Desalegn ${ }^{3}$, Zerihun Woldu', Sebsebe Demissew ${ }^{1}$ and Ermias Teferi ${ }^{4}$
}

\begin{abstract}
Introduction: Soil is the major reservoir of organic carbon. There is a paucity of soil organic carbon (SOC) stock data of afroalpine and sub-afroalpine vegetation in Ethiopia. Hence, this study was conducted to estimate the SOC stock and correlate it with soil physicochemical properties in Abune Yosef afroalpine and sub-afroalpine vegetation. Systematic sampling was employed to collect soil samples from upper $30 \mathrm{~cm}$. Dry bulk density soil pH (1:2.5 water); organic carbon (Walkley and Black), and total nitrogen (Kjeldahl) were the methods used for soil analysis. Pearson correlation and linear regression analysis were performed in SPSS 24 statistical software.

Results: The SOC stock of the study area was found to be $79.57 \mathrm{t} \mathrm{C} \mathrm{ha}{ }^{-1}$. Soil organic carbon stock showed statistically significant positive correlation with vegetation type $(r=0.522, p<0.01)$, bulk density $(r=0.62, p<0.01)$, total nitrogen $(r=0.41, p<0.01)$, and altitude $(r=0.468, p<0.01)$ and negative correlation with slope $(r=-0.298$, $p<0.05$ ). The present study revealed similar soil organic carbon stock (SOCS) with the Intergovernmental Panel on Climate Change (IPCC) default estimate for similar regions. Positive correlation of SOCS and altitude could be resulted from the variations in anthropogenic disturbances, temperature, and precipitation vegetation types. The negative correlation between SOCS and slope is the result from the predictably higher soil erosion at steeper slopes. Temporal livestock trampling increased the bulk density but never affected the SOCS to decline. Aspect did not show any significant relationship with SOCS due to either the under surveying of all aspects or similar solar radiation found in the study area. Moreover, gazing, aspect, and soil pH did not show statistically significant impact on SOCS.
\end{abstract}

Conclusion: The SOCS of Abune Yosef afroalpine and sub-afroalpine vegetation is similar to the IPCC default estimate for similar regions. This is a great contribution both to the global and local terrestrial carbon sink.

Keywords: Abune Yosef, Afroalpine and sub-afroalpine vegetation, Altitude gradient, Correlation, Organic carbon stock, Vegetation type

\section{Introduction}

It is obvious that soil is required by almost all living organisms in the terrestrial ecosystem. Besides the myriad importance of soil, it is the major reservoir of organic carbon which plays a crucial role in the global carbon cycle. Furthermore, the concentration of soil organic carbon (SOC) is used as an indicator of soil health and quality (Waring et al. 2014). SOC is estimated to be

\footnotetext{
* Correspondence: kflay77@gmail.com; kflay.gebrehiwot@aau.edu.et ${ }^{1}$ Department of Plant Biology, Addis Ababa University, P.O.Box 3434, Addis Ababa, Ethiopia

${ }^{2}$ Department of Biology, Samara University, Semera, Afar, Ethiopia Full list of author information is available at the end of the article
}

more than $2000 \mathrm{Pg}$ of carbon (C) in the upper $100 \mathrm{~cm}$ of soil depth (Batjes 1996) which is by far higher than the cumulative SOC stock of the atmosphere and vegetation (Lal 2004).This reveals strong potential in mitigating climate change (Vagen and Winowiecki 2013; Lal 2004) because it has a strong influence on the carbon dioxide $\left(\mathrm{CO}_{2}\right)$ concentration in the atmosphere (Genxu et al. 2002). Due to the unsustainable utilization of resources and land use systems, however, carbon is lost at an alarming rate. The current carbon loss is estimated to be $1.6 \pm 0.8 \mathrm{Pg} \mathrm{C}$ year $^{-1}$, mainly in the tropics (Smith 2008). Furthermore, Crowther et al. (2016) estimated that carbon stock loss from the upper soil horizon is 
estimated to be $55 \pm 50 \mathrm{Pg}$ by 2050 , which is about $17 \%$ of the expected anthropogenic emissions over this period (Ballantyne et al. 2015).

Africa adds 9\% SOC, about $166,397 \mathrm{Tg} \mathrm{C}$ in 0 to 100 $\mathrm{cm}$ soil layer, to the global SOC stock and $68 \%$ of the terrestrial carbon pool of Africa (Henry et al. 2009). The SOC stock in 0 to100-cm soil layer of Ethiopia revealed that $6459 \mathrm{Tg}$ (or million tonnes) of C (Henry et al. 2009) which is more than $14 \%$ of the eastern Africa SOC stock. However, soil erosion together with deforestation and land use changes caused the loss of 15 to $1000 \mathrm{~kg} \mathrm{C} \mathrm{ha}^{-1}$ year $^{-1}$ in Ethiopia (Demessie et al. 2017). Ethiopia owns a diverse topography which ranges from $126 \mathrm{~m}$ below sea level to above $4533 \mathrm{~m}$ above sea level (m.a.s.l). Consequently, it harbors very diverse soil types. However, there is a paucity in the SOC stock assessment researches particularly in the afroalpine and sub-afroalpine vegetation types, above 3200 m.a.s.l. This is due to the cold temperature because these vegetation types did not support crop production. These are usually areas above the treeline, i.e., they are dominated by life forms different from the lower altitudes such as giant rosette plants, tussock, and mat-forming plants (Erica arboria, Lobelia rynchopetalum, Helichrysum species, Alchemilla species, Festuca abyssinica, Euryops pinifolius, Kniphofia foliosa, etc.) which are some of the characteristic species of this vegetation type.

Mountain ecosystems are important carbon reservoirs. They store about $26 \%$ of the terrestrial carbon (Charles and Hanson 2006). However, Ethiopian mountain ecosystems in general and Abune Yosef mountain, in particular, are facing anthropogenic pressures due to the ever-increasing population and man-induced climate change. Agricultural expansion to the higher elevations is a common practice in Abune Yosef mountains. Although the mountain is designated as a community conservation area, perturbations to the ecosystem are still persisting. Consequently, Abune Yosef mountain is a highly degraded ecosystem, and the remnant of afroalpine vegetation remains is above 3800 m.a.s.l. This could critically influence the SOC stock of the mountain. Moreover, there is a paucity of SOC stock data on afroalpine and sub-afroalpine vegetation in Ethiopia because most of SOC stock researches in Ethiopia are on agricultural lands. The only article on this vegetation type to date is on Bale Mountains (Yimer et al. 2006). Hence, estimating the SOC stock of the study area would have a strong contribution for to management and conservation of soil in the study area and other similar vegetation types of Ethiopia. Furthermore, it could also help to understand the crucial role of soil in the global carbon cycle.

The objectives of the present study were, thus, to estimate the SOC stock and correlate the physicochemical properties of soil that influence SOC stock in Abune
Yosef afroalpine and sub-afroalpine vegetation, northern Ethiopia.

\section{Methods \\ Study area description}

Abune Yosef mountain (AYM) is found in Amhara Regional State, North Wollo Zone, Lasta district, at a latitude of $12^{\circ} 7^{\prime}$ to $12^{\circ} 9^{\prime} \mathrm{N}$ and longitude $39^{\circ} 9^{\prime}$ to $39^{\circ} 11^{\prime}$ E (Fig. 1). According to Friis et al. (2010), it is the seventh highest mountain in Ethiopia. Its altitude reaches up to 4284 m.a.s.l. The fragmented ericaceous forest starts at about 3000 m.a.s.l and terminates at about 3300 m.a.s.l. It is dominated by Erica arborea. The peak of the mountain is a basaltic rock. The peak is, thus, covered by either a bare rock or plants which are adapted to shady places at the base of rocks. The ridges of AYM extend northeastwards to the Tigray mountains through lower systems and northwestwards to the Semien Mountains (4533 m.a.s.l). It is from this massif where the Tekeze River rises.

\section{Geology, soil, and climate}

The mountains of northern Ethiopia consist of a high basaltic plateau situated west of the main Ethiopian rift (Coltorti et al. 2007). The climate of Ethiopian mountains is mainly controlled by the Intertropical Convergence Zone (ITCZ), which reaches its southern position in January, thus strengthening the NE trade winds which induce clear conditions with diurnal frost above 3700 m.a.s.l (Grab 2002). The highest rainfall is observed in the kiremt (main rainy season) and belg (smaller rainy season) seasons. However, this has been reducing by 15$20 \%$ in several parts of the country since 1970 (FEWSNET 2012). Furthermore, the projection of the report showed that there would be a decline of rainfall by about $150 \mathrm{~mm} /$ year and an increase of temperature by more than $1.0{ }^{\circ} \mathrm{C}$ in between 2010 and 2039 in most parts of Ethiopia.

The rainfall data of 1993-2014 was obtained from Ethiopian National Meteorological Agency (ENMA) Lalibela station, 2500 m.a.s.l. The temperature data is, however, collected from grid and satellite data from ENMA at an altitude of 4284 m.a.s.l. The monthly maximum and minimum temperatures of AYM are $26.6{ }^{\circ} \mathrm{C}$ and $4{ }^{\circ} \mathrm{C}$, respectively. The climate diagram showed that AYM receives an unbimodal rainfall of about $790 \mathrm{~mm} /$ year in which highest rainfall is received during kiremt (Fig. 2).

The soil type in the study area is dominantly andosol. Furthermore, the soil texture is silty clay, silty clay loam, and clay loam (Fig. 3).

\section{Soil sampling}

Five replicate soil samples were taken, four from the corners and one from the center, from a rectangular $5 \times$ 


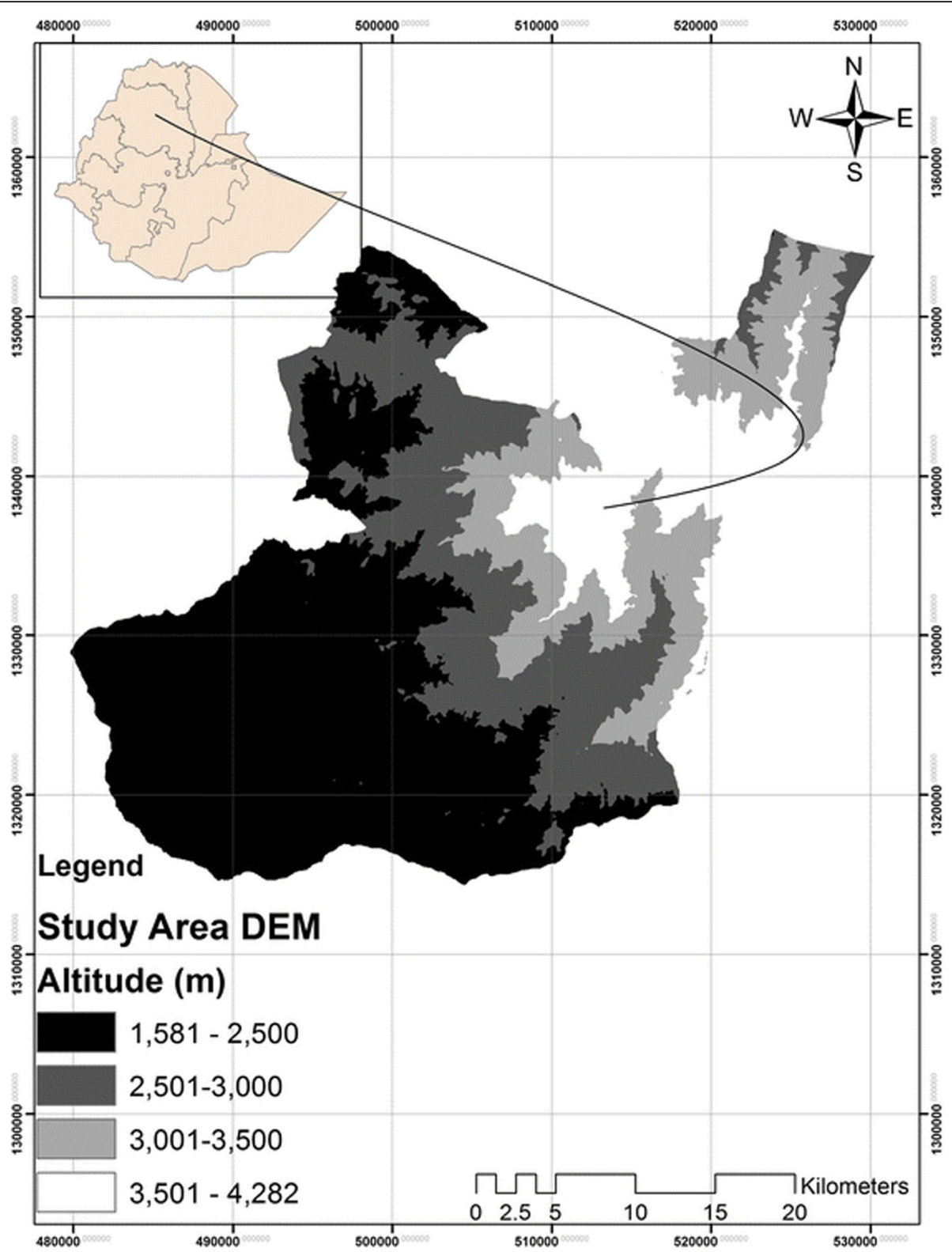

Fig. 1 Map of the study area

$5 \mathrm{~m}$ sample plot at $100 \mathrm{~m}$ interval at $0-30 \mathrm{~cm}$ depth. Samples were collected by trowels. The replicates were mixed thoroughly and bulked to make a composite sample so that one sample is taken from each plot for analysis. Elevation and slope of each plot were recorded by using handheld Garmin GPS H72 and Suunto clinometer, respectively. Moreover, grazing intensity of each plot was conventionally estimated and coded as (1) slight grazing; (2) medium grazing; and (3) severe grazing. Vegetation cover of each plot was also estimated visually. Soil samples were air dried, gently crushed, and passed through a 2-mm sieve for chemical analysis.

\section{Soil analysis}

Dry bulk density was analyzed following Maynard and Curran (2008), soil pH (Hendershot et al. 2008); organic carbon was analyzed according to Walkley and Black method (Walkley and Black 1934), while total nitrogen (TN) was analyzed by Kjeldahl method (Rutherford et al. 2008). However, due to the high soil organic matter, potassium dichromate $\left(\mathrm{K}_{2} \mathrm{O}_{2} \mathrm{Cr}_{7}\right)$ and sulfuric acid $\left(\mathrm{H}_{2} \mathrm{SO}_{4}\right)$ solutions were doubled to 20 and $40 \mathrm{ml}$, respectively, for $0.5 \mathrm{~g}$ soil weight. Soil analysis was performed at Holetta Agricultural Research Center (HARC). Soil organic carbon stock was calculated for each sample plot as follows: 


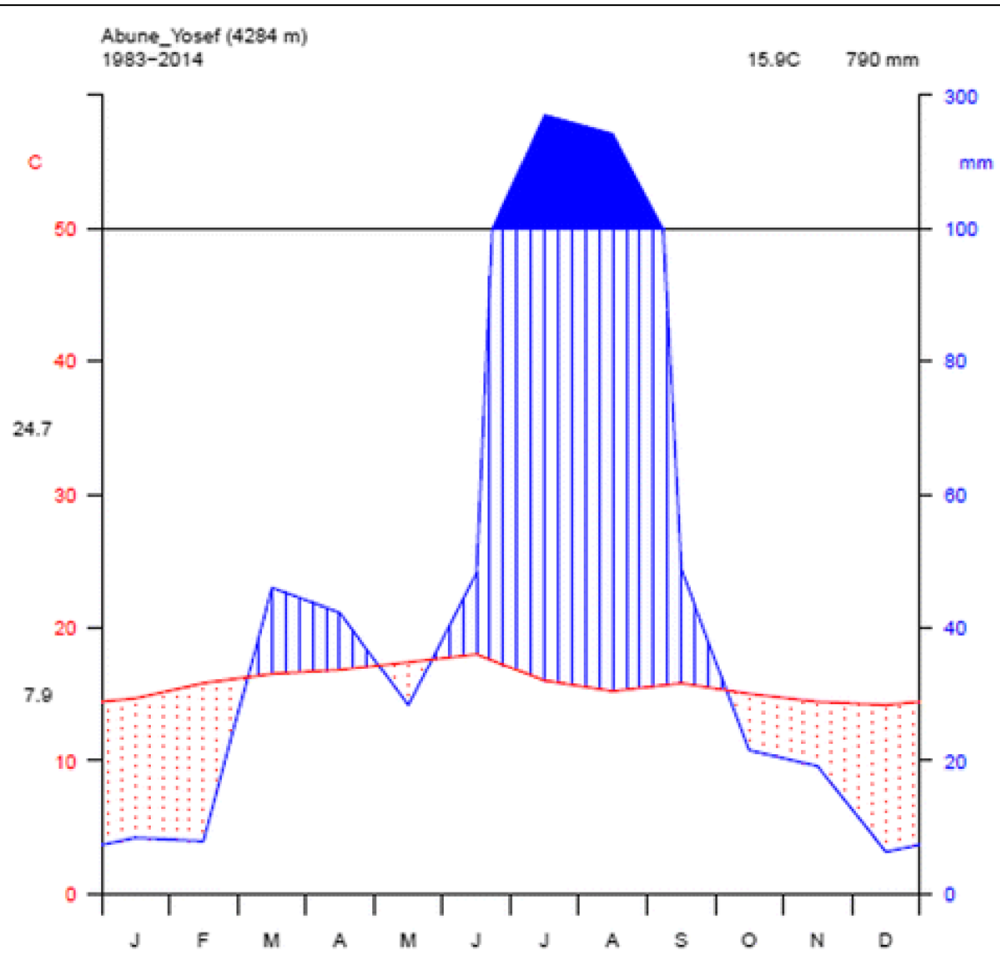

Fig. 2 Climate diagram of the study area

$$
\text { SOCsp }=\% \mathrm{C} \times \mathrm{D} \times \mathrm{BDsp}
$$

Where, SOCsp $=$ soil organic carbon stock $\left(\mathrm{g} \mathrm{cm}^{-2}\right)$ of a sample plot, \%Csp = carbon concentration $\left(\mathrm{g} \mathrm{C} \mathrm{kg}^{-1}\right)$ of a sample plot, and $\mathrm{BD}=$ bulk density $\left(\mathrm{g} \mathrm{cm}^{-3}\right)$ of a sample plot.

It was reported in hectare base according to Eq. 2.

$$
\begin{aligned}
\operatorname{SOCsp}\left(\mathrm{tha}^{-1}\right)= & \left(\frac{\text { Carbon Concentration }}{100}\right) \\
& \times \text { bulk density }\left(\frac{\mathrm{g}}{\mathrm{cm}^{3}}\right) \\
& \times \text { depth }(\mathrm{cm})
\end{aligned}
$$

The SOC stock of the study area is, thus, the sum of the SOCsp.

$$
\text { SOC Stock }=\sum_{i=1}^{n} \text { SOCsp }
$$

\section{Statistical analysis}

Soil organic carbon stock (SOCS) was correlated with total nitrogen (TN), bulk density (BD), soil pH, elevation, slope, aspect, vegetation type, and grazing level by using Pearson correlation coefficient and linear regression analysis using SPSS version 24 software package.

\section{Results}

Descriptive statistics (Table 1) showed that the minimum and maximum bulk densities were 0.46 and $1.40 \mathrm{~g} \mathrm{~cm}^{-3}$, respectively, with a mean bulk density of $0.7 \pm 0.19 \mathrm{~g} \mathrm{~cm}^{-3}$. The mean soil organic carbon was $7.7 \pm 1.62 \%$ with a minimum 3.59 and maximum $11.22 \%$. Soil $\mathrm{pH}$ showed a little variation with minimum and maximum $\mathrm{pH}$ of 5.23 and 6.58, respectively, along altitude gradient. The soil organic carbon stock of the study area was found to be $79.57 \mathrm{t} \mathrm{C} \mathrm{ha}^{-1}$. Although it does not show a statistically significant variation, afroalpine grassland found to have higher SOC stock than the ericaceous forest with a mean SOCS of 1.79 and 1.29 t C ha $^{-1}$.

The study revealed that soil organic carbon stock showed a negative correlation with grazing, $\mathrm{pH}$, and positive correlation with aspect (Table 2). However, the correlations were statistically significant positive with vegetation type $(r=0.522, p<0.01)$, bulk density (BD) $(r=0.62, p<0.01)$, nitrogen $(r=0.41, p<0.01)$, and altitude $(r=0.468, p<0.01)$ and negative correlation with slope $(r=-0.298, p<0.05)$ (Fig. $4 \mathrm{a}-\mathrm{f})$. The distribution of SOCS along altitude gradient followed an increasing trend.

\section{Discussion}

The Soil Atlas of Africa (Jones et al. 2013) reported that the average SOC stock for the continent at $0-30 \mathrm{~cm}$ 


\section{SOIL TEXTURE}

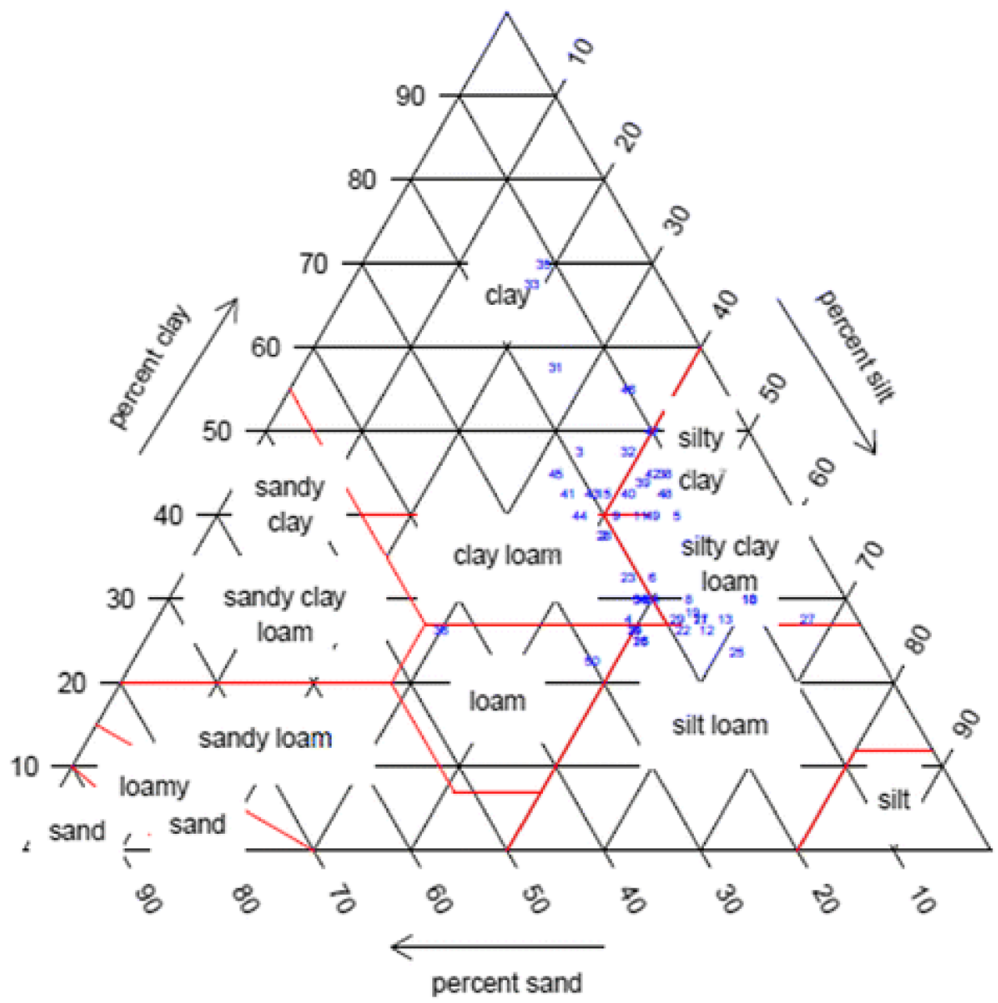

Fig. 3 Soil texture triangle of the study area

depth is $35.08 \mathrm{t} \mathrm{C} \mathrm{ha}^{-1}$. On the other hand, the SOC stock of the upper $30 \mathrm{~cm}$ soil in tropical montane was estimated to be $80 \mathrm{t} \mathrm{C} \mathrm{ha}^{-1}$ (IPCC 2006). The present study, however, revealed higher SOCS than reported by the Soil Atlas of Africa while it is similar with to the IPCC default estimate for similar regions. It is, however, by far lower than a study from Tanzania (Munishi and Shear 2004). Nevertheless, it falls in the global average which is $3-41 \mathrm{~kg} \mathrm{C} \mathrm{m}^{-2}$ (Batjes 1996). It is also

Table 1 Descriptive statistics of variables

\begin{tabular}{llllll}
\hline & N & Minimum & Maximum & Mean & Std. deviation \\
\hline SOC stock & 50 & 0.63 & 2.66 & 1.59 & 0.47 \\
SOC & 50 & 3.59 & 11.22 & 7.70 & 1.62 \\
BD & 50 & 0.46 & 1.40 & 0.70 & 0.19 \\
N & 50 & 0.03 & 1.20 & 0.65 & 0.19 \\
Altitude & 50 & 3014.00 & 4168.00 & 3691.78 & 417.08 \\
Grazing & 50 & 1.00 & 3.00 & 1.86 & 0.88 \\
Aspect & 50 & 0.00 & 3.30 & 1.47 & 0.80 \\
Slope & 50 & 2.00 & 35.00 & 15.98 & 8.42 \\
Vegetation type & 50 & 1.00 & 2.00 & 1.60 & 0.49 \\
pH & 50 & 5.23 & 6.58 & 5.85 & 0.31 \\
\hline
\end{tabular}

consistent with the results of alpine and sub-alpine grassland somewhere in the world (Garcia-pausas et al. 2007).

The present study revealed a positive correlation of SOCS with altitude. The anthropogenic disturbances are higher at the lower altitudes (for example, logging and wood collection in the ericaceous forest) and lower at the higher altitude (afroalpine grasslands). There is also temperature (higher in the ericaceous belt and lower in the afroalpine grassland) and precipitation (lower in the ericaceous belt and higher in the afroalpine grassland) variation along the altitude altitudinal gradient. These could be some of the many reasons for the increasing trend of SOCS along an altitude altitudinal gradient. Several studies reported a positive correlation of SOCS with altitude (Dar and Somaiah 2015; Du et al. 2014; He et al. 2016; Parras-Alcántara et al. 2015). Furthermore, a research in the dry evergreen Afromontane forest of Ethiopia by Feyissa et al. (2013) also showed an increasing trend of SOC stock along altitude gradient. This could be due to the decreased decomposition in relation to the production and long-term accumulation of organic carbon (Bolstad and Vose 2001). However, a study from Himalaya reported the decrease of SOC with 
Table $\mathbf{2}$ Correlation of SOC stock with selected variables

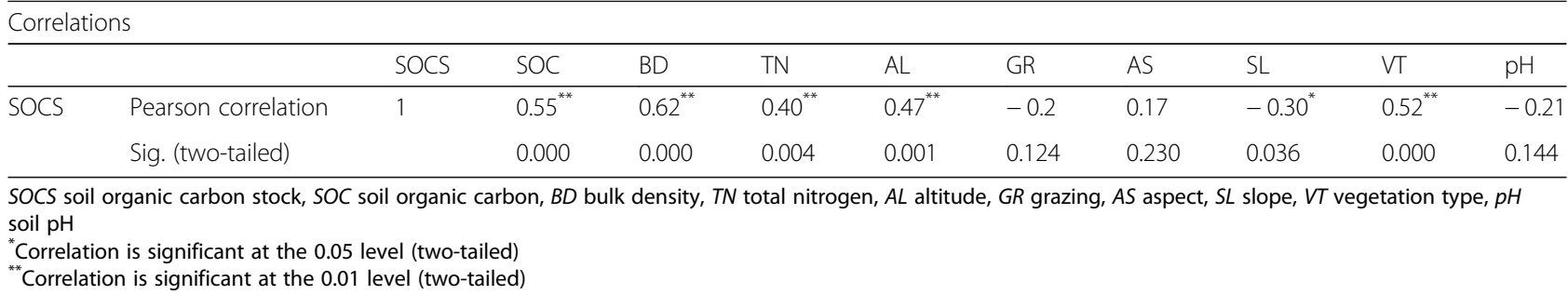

increasing altitude (Sheikh et al. 2009). Consequently, Tsui et al. (2013) claimed that altitude is possibly a simple and effective predictor of SOC stock.

Slope was found to be negatively correlated with soil organic carbon stock. This seems a little tricky considering the positive correlation of SOCS with altitude. However, the afroalpine grassland is a sort of plateau which is found at higher altitudes, and it possesses the lower slopes whereas the ericaceous belt possesses higher slopes and lower elevations altitude. Furthermore, soil erosion is predictably higher at steeper slopes removing soil organic carbon and other nutrients, which leads to declined SOCS. Similar relationships were reported from another region parts of the world (Bolstad and Vose 2001). On the contrary, Hamere et al. (2015) found no relationships between soil organic carbon stock and slope of southwest Ethiopia. The difference might be emanated from the slope scales used and the vegetation cover of the study areas.

Bulk density was positively correlated with SOCS. Previous studies (Potter et al. 2001; Reeder et al. 2004) have reported the positive correlation between bulk density and SOCS. A very small increase in bulk density has increased the SOCS (Bolstad and Vose 2001). On the contrary, the negative correlation of bulk density with SOCS was reported (Dar and Somaiah 2015). In the present study, temporal livestock trampling, particularly in the grassland, could have increased the bulk density but never affected the SOCS to decline. Experimental research in temperate and subtropical grasslands of South America by Pineiro et al. (2009) showed that an exclusion of cattle has decreased bulk density.

Grazing reduces SOC stock (Martinsen et al. 2011; Zhao et al. 2014). A study in Ethiopia also reported a highly strongly significant difference of SOC stock between grazing land and area exclosure, i.e., highest in the area exclosure (Girmay and Singh 2012; Mekuria 2013). However, the present study found no statistically significant relationships between grazing and SOCS. Even though grazing was recorded at the top ridge of the mountain, it was not in a condition to significantly affect the SOCS.

Climate and vegetation types are some of the main variables which influence SOC in the ecosystems
(Doblas-Miranda et al. 2013; Henkner et al. 2016). Similarly, the present study found that vegetation type has a strong influence on soil organic carbon stock. The afroalpine grassland has higher SOC stock than the ericaceous forest. This could be due to the minimum anthropogenic disturbances emanated from its inaccessibility and the relatively lower slopes which are not prone to soil erosion. Higher SOC stock of grassland than a forest was reported somewhere in Spain (Willaarts et al. 2016). Although it is in the upper $5 \mathrm{~cm}$, Chibsa and Asefa (2009) also found a higher SOC stock in grasslands.

Previous researches on relationships of SOC and $\mathrm{pH}$ are scanty. A negative correlation of $\mathrm{pH}$ and $\mathrm{SOC}$ was reported in New Zealand (McIntosh and Allen 1993). On the contrary, a study from Australia found no significant correlation between soil $\mathrm{pH}$ and SOCS (Holmes et al. 2017). In the present study, there appears no significant correlation between $\mathrm{pH}$ and SOCS. The soil $\mathrm{pH}$ showed a very minor variation along the elevation gradient.

Although aspect effect is not highly pronounced like the temperate region, it can influence the vegetation distribution in the tropics due to its impact on microclimate. Consequently, its impact could be reflected in SOC stock. Researchers have investigated the relationship of aspect with soil organic carbon. A research in Bale Mountain, Ethiopia, by Yimer et al. (2006) reported statistically significant positive correlation between aspect and SOC stock. However, Måren et al. (2015) found no significant relationship between SOC stock and aspect, north and south facing in a semi-arid transHimalayan valley. There was a weak non-significant positive correlation in the present study. This might be due to either the under surveying of all aspects due to inaccessibility and bare lands or similar solar radiation found in the study area. Samples were collected from southwest, northwest, southeast, northeast, and north exclusive to pure east, west, and south.

Carbon and nitrogen are an important component of the ecosystem both for plant growth and climate change. The larger the stock of SOC and TN, the larger contribution to climate change and global warming. Soil organic carbon stock and total nitrogen followed the same 

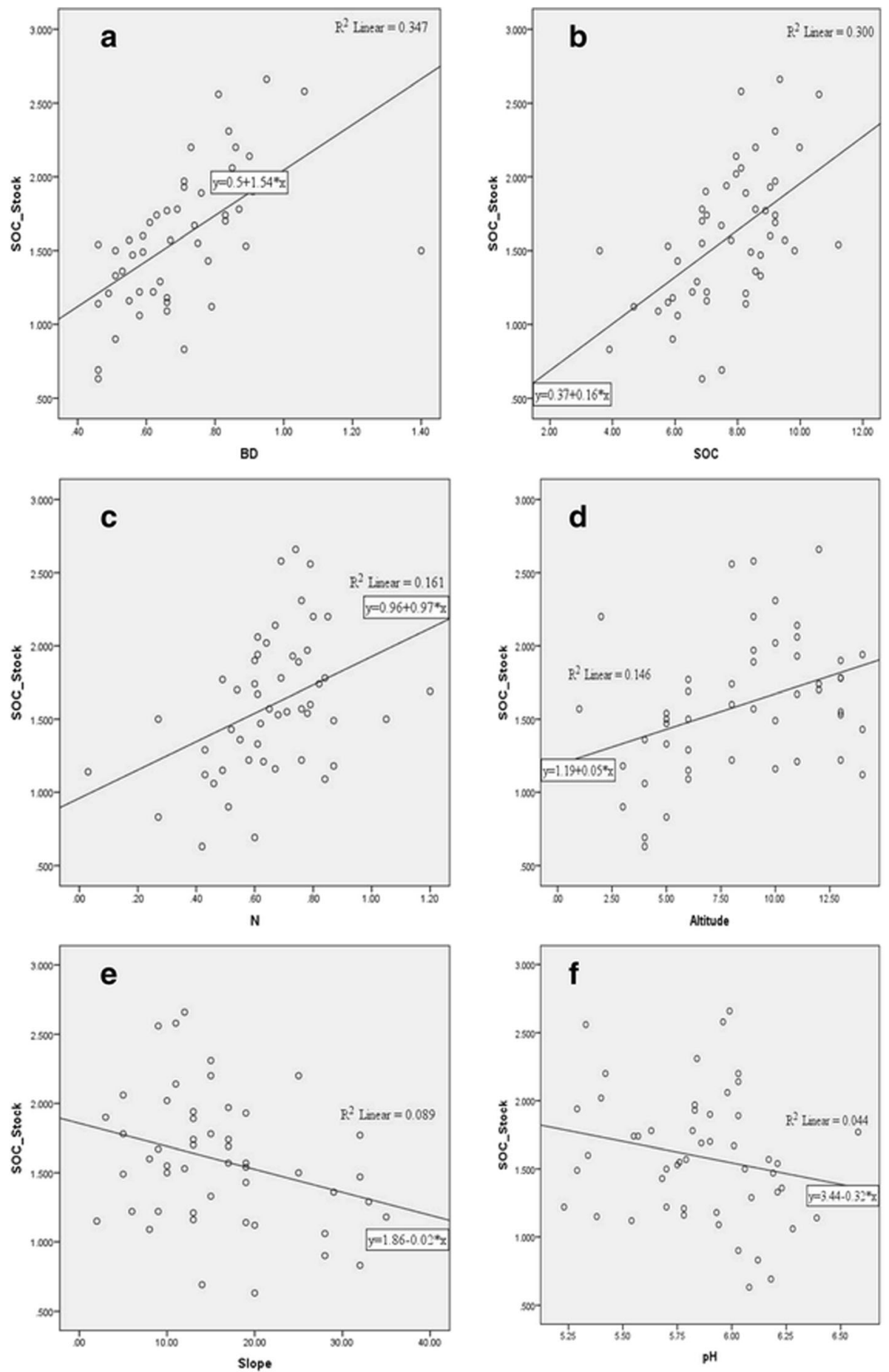

Fig. 4 a-f Scatter plots of SOC stock as the response variable and a bulk density, $\mathbf{b}$ SOC, $\mathbf{c}$ total nitrogen, $\mathbf{d}$ altitude, e slope, and $\mathbf{f}$ soil $\mathrm{pH}(p<0.05)$

pattern with a strong positive correlation (Potter et al. 2001; Ying-zi et al. 2013). Consistent with the researches stated, the present study revealed very strong positive correlation between SOCS and TN.

\section{Conclusions}

The SOCS of Abune Yosef afroalpine and sub-afroalpine vegetation is similar to the IPCC default estimate for similar regions. This is a great contribution both to the 
global and local to the terrestrial carbon sink. SOC stock showed statistically significant positive correlation with vegetation type, bulk density, and altitude and negative correlation with slope. Temporal livestock trampling may have caused the increased bulk density of the grassland.

\section{Abbreviations}

AYM: Abune Yosef mountain; BD: Bulk density; ENMA: Ethiopian National Meteorological Agency; IPCC: Intergovernmental Panel on Climate Change; m.a.s.l: Meter above sea level; SOC: Soil organic carbon; SOCS: Soil organic carbon stock; TN: Total nitrogen

\section{Acknowledgements}

We would like to thank the Addis Ababa University for funding this research. We are also grateful to all the staff members of Holetta Agricultural Research Center (HARC) particularly for the soil and plant analysis.

\section{Funding}

The funding sponsor, Addis Ababa University, had no role in the design of the study; in the collection, analyses, or interpretation of data; in the writing of the manuscript; and in the decision to publish the results.

\section{Authors' contributions}

KG was involved in the conception, field data collection, and analysis and wrote the manuscript. TD and ZW were involved in the conception and analysis of data. Furthermore, TD facilitated and performed the experiment. Whereas, SD and ET were part of the analysis and interpretation and organized the manuscript. All authors read and approved the final manuscript.

\section{Competing interests}

The authors declare that they have no competing interests.

\section{Publisher's Note}

Springer Nature remains neutral with regard to jurisdictional claims in published maps and institutional affiliations.

\section{Author details}

'Department of Plant Biology, Addis Ababa University, P.O.Box 3434, Addis Ababa, Ethiopia. ${ }^{2}$ Department of Biology, Samara University, Semera, Afar, Ethiopia. ${ }^{3}$ Holetta Agricultural research Center, Holetta, Ethiopia. ${ }^{4}$ Center for Environmental and Developmental Studies, Addis Ababa University, Addis Ababa, Ethiopia

Received: 14 November 2017 Accepted: 23 January 2018

Published online: 16 February 2018

\section{References}

Ballantyne AP, Andres R, Houghton R et al (2015) Audit of the global carbon budget: estimate errors and their impact on uptake uncertainty. Biogeosciences 12:2565-2584

Batjes NH (1996) Total carbon and nitrogen in the soils of the world. Eur J Soil Sci 47:151-163

Bolstad PV, Vose JM (2001) The effect of terrain position and elevation on soil C in the southern Appalachians. In: Lal R, Kimble JM, Follett RF, Stewart BA (eds) Assessment methods for soil carbon. Lewis publishers, Boca Raton.

Charles G, Hanson PJ (2006) Measured forest soil C stocks and estimated turnover times along an elevation gradient. Geoderma 136:342-352. https:// www.doi.org/10.1016/j.geoderma.2006.03.049

Chibsa T, Asefa T (2009) Assessment of soil organic matter under four land use systems in Bale Highlands, south east Ethiopia: A. soil organic matter contents in four land use systems: forestlands, grasslands, fallow land and cultivated land. World Appl Sci J 6:1231-1246.

Coltorti M, Dramis F, Ollier CD (2007) Plantation surfaces in northern Ethiopia. Geomorphology 89:287-296. https://www.doi.org/10.1016/j.geomorph.2 006.12 .007
Crowther TW, Todd-Brown KEO, Rowe CW et al (2016) Quantifying global soil carbon losses in response to warming. Nature 540:104-108. https://www.doi. org/10.1038/nature20150

Dar JA, Somaiah S (2015) Altitudinal variation of soil organic carbon stocks in temperate forests of Kashmir Himalayas, India. Environ Monit Assess 187:11. https://www.doi.org/10.1007/s10661-014-4204-9

Demessie A, Singh BR, Lal R (2017) Soil carbon sequestration: Ethiopia. Encycl. Soil Sci, pp 2066-2072.

Doblas-Miranda E, Rovira P, Brotons L et al (2013) Soil carbon stocks and their variability across the forests, shrublands and grasslands of peninsular Spain. Biogeosciences 10:8353-8361. https://www.doi.org/10.5194/bg-10-8353-2013

Du B, Kang H, Pumpanen J et al (2014) Soil organic carbon stock and chemical composition along an altitude gradient in the Lushan mountain, subtropical China. Ecol Restor 29:433-439. https://www.doi.org/10.1007/s11284014-1135-4

FEWSNET (2012) A climate trend analysis of Ethiopia: fact sheet, pp 2012-3053.

Feyissa A, Soromessa T, Argaw M (2013) Forest carbon stocks and variations along altitudinal gradients in Egdu Forest: implications of managing forests for climate change mitigation. Sci Technol Arts Res J 2:40-46.

Friis I, Demissew S, van Breugel P (2010) Atlas of the potential vegetation of Ethiopia atlas of the potential vegetation of Ethiopia. The Royal Danish Academy of Sciences and Letters, Copenhagen.

Garcia-pausas J, Casals P. Camarero L et al (2007) Soil organic carbon storage in mountain grasslands of the Pyrenees: effects of climate and topography. Biogeochemistry 82:279-289. https://www.doi.org/10.1007/s10533-007-9071-9

Genxu W, Ju Q, Guodong C, Yuanmin L (2002) Soil organic carbon pool of grassland soils on the Qinghai-Tibetan Plateau and its global implication. Sci Total Environ 291:207-217.

Girmay G, Singh BR (2012) Changes in soil organic carbon stocks and soil quality: land-use system effects in northern Ethiopia. Acta Agric Scand Sect B Soil Plant Sci 62:519-530. https://www.doi.org/10.1080/09064710.2012.663786

Grab S (2002) Glacial and periglacial phenomena in Ethiopia: a review. Permafr Periglac Process 13:71-76. https://www.doi.org/10.1002/ppp.405

Hamere Y, Soromessa T, Argaw M (2015) Carbon stock analysis along slope and slope aspect gradient in Gedo Forest: implications for climate change mitigation. Earth Sci Clim Chang 6:305. https://www.doi.org/10.4172/21577617.1000305

He X, Hou E, Liu Y, Wen D (2016) Altitudinal patterns and controls of plant and soil nutrient concentrations and stoichiometry in subtropical China. Sci Rep 6:1-9. https://www.doi.org/10.1038/srep24261

Hendershot WH, Lalande H, Duquette M (2008) Soil reaction and exchangeable acidity. In: Carter MR, Gregorich EG (eds) Soil sampling and methods of analysis, second. CRC Press, USA

Henkner J, Scholten T, Kühn P (2016) Geoderma soil organic carbon stocks in permafrost-affected soils in West Greenland. Geoderma 282:147-159. https:// www.doi.org/10.1016/j.geoderma.2016.06.021

Henry M, Valentini R, Bernoux M (2009) Soil carbon stocks in ecoregions of Africa. Biogeosci Discuss 6:797-823.

Holmes K, Holye F, Pathan S, et al (2017) Fact sheets soil organic carbon storage in the Western Avon Basin-WA. https://soilquality.org.au/factsheets/soilorganic-carbon-storage-in-the-western-avon-basin-w-a. Accessed 26 Sept 2017.

IPCC (2006) 2006 IPCC guidelines for national greenhouse gas inventories: agriculture, forestry, and other land uses, 4th edn. IGES, Hayama.

Jones A, Breuning-Madsen H, Brossard M et al (eds) (2013) Soil Atlas of Africa. European Commission, Publications Office of the European Union, Luxembourg.

Lal R (2004) Soil carbon sequestration to mitigate climate change. Geoderma 123:1-22. https://www.doi.org/10.1016/j.geoderma.2004.01.032

Måren I, Karki S, Prajapati C, Kailash R (2015) Facing north or south: does slope aspect impact forest stand characteristics and soil properties in a semiarid trans-Himalayan. J Arid Environ 121:112-123. https://www.doi.org/10.1016/j. jaridenv.2015.06.004

Martinsen V, Mulder J, Austrheim G, Mysterud A (2011) Carbon storage in lowalpine grassland soils: effects of different grazing intensities of sheep. Eur J Soil Sci 62:822-833. https://www.doi.org/10.1111/j.1365-2389.2011.01393.x

Maynard DG, Curran MP (2008) Bulk density measurement in forest soils. In: Carter MR, Gregorich EG (eds) Soil sampling and methods of analysis, second. CRC Press, USA.

Mclntosh PO, Allen RB (1993) Soil pH declines and organic carbon increases under hawkweed (Hieracium pilosella). N Z J Ecol 17:59-60. 
Mekuria W (2013) Changes in regulating ecosystem services following establishing exclosures on communal grazing lands in Ethiopia: a synthesis. J Ecosyst. https://www.doi.org/10.1155/2013/860736. Research

Munishi PKT, Shear TH (2004) Carbon storage in Afromontane rainforests of the eastern arc mountains of Tanzania: their net contribution to atmospheric carbon. J Trop For Sci 16:78-93.

Parras-Alcántara L, Lozano-García B, Galán-Espejo A (2015) Soil organic carbon along an altitudinal gradient in the Despeñaperros Natural Park, southern Spain. Solid Earth 6:125-134. https://www.doi.org/10.5194/se-6-125-2015

Pineiro G, Paruelo M, Jobbagy EG et al (2009) Grazing effects on belowground C and $\mathrm{N}$ stocks along a network of cattle exclosures in temperate and subtropical grasslands of South America. Glob Biogeochem Cycles 23: GB2003. https://www.doi.org/10.1029/2007GB003168

Potter K, Daniel J, Altom W, Torbert H (2001) Stocking rate effect on soil carbon and nitrogen in degraded soils. J Soil Water Conserv 56:233-236.

Reeder JD, Schuman G, Morgan J, Lecain D (2004) Response of organic and inorganic carbon and nitrogen to long-term grazing of the shortgrass steppe. Environ Manag 33:485-495.

Rutherford PM, McGill WB, Arocena JM (2008) Total Nitrogen. In: Carter MR, Gregorich EG (eds) Soil sampling and methods of analysis, second. CRC Press, USA.

Sheikh MA, Kumar M, Bussmann RW (2009) Altitudinal variation in soil organic carbon stock in coniferous subtropical and broadleaf temperate forests in Garhwal Himalaya. Carbon Balance Manag 4(1):6. https://www.doi.org/10.11 86/1750-0680-4-6

Smith P (2008) Soil organic carbon dynamics and land-use change. In: Braimoh AK, Vlek PLG (eds) Land use and soil resources. Springer, New York.

Tsui C, Tsai C, Chen Z (2013) Geoderma soil organic carbon stocks in relation to elevation gradients in volcanic ash soils of Taiwan. Geoderma 209-210:119127. https://www.doi.org/10.1016/j.geoderma.2013.06.013

Vagen T-G, Winowiecki L (2013) Mapping of soil organic carbon stocks for spatially explicit assessments of climate change mitigation potential. Environ Res Lett 8(9pp):015011. https://www.doi.org/10.1088/1748-9326/8/1/015011

Walkley A, Black CA (1934) An examination of the degrjareff method of determining soil organic matter and a proposed modification of chromic acid titration method. Soil Sci 37:29-38.

Waring C, Stockmann U, Malone BP et al (2014) Is percent "projected natural vegetation soil carbon" a useful indicator of soil condition? In: Hartemink AE, Mcsweeney K (eds) Soil Carbon. Springer, New York

Willaarts BA, Oyonarte C, Muñoz-rojas M et al (2016) Environmental factors controlling soil organic carbon stocks in two contrasting Mediterranean climatic areas of southern Spain. Land Degrad Dev 27:603-611.

Yimer F, Ledin S, Abdelkadir A (2006) Soil organic carbon and total nitrogen stocks as affected by topographic aspect and vegetation in the Bale Mountains, Ethiopia. Geoderma 135:335-344. https://www.doi.org/10.1016/j. geoderma.2006.01.005

Ying-zi CAO, Xiao-dan W, Xu-yang LU et al (2013) Soil organic carbon and nutrients along an alpine grassland transect across northern Tibet. J Mt Sci 10:564-573. https://www.doi.org/10.1007/s11629-012-2431-5

Zhao L, Wu W, Xu X, Xu Y (2014) Soil organic matter dynamics under different land use in grasslands in Inner Mongolia ( northern China ). Biogeosciences 11:5103-5113. https://www.doi.org/10.5194/bg-11-5103-2014

\section{Submit your manuscript to a SpringerOpen ${ }^{\circ}$ journal and benefit from:}

- Convenient online submission

- Rigorous peer review

- Open access: articles freely available online

- High visibility within the field

- Retaining the copyright to your article

Submit your next manuscript at $\boldsymbol{\nabla}$ springeropen.com 